\title{
Use of General Preservation Assessments
}

\section{Process}

\section{Karen E. K. Brown}

This paper describes the typology of general preservation assessments and investigates what is being accomplished based on recommendations identified in the process. The author characterizes the assessment based on tabulated data. A range of institutional types and sizes are represented. The investment of staff time and the role of the consultant are examined. The most frequent goal of respondents was to develop a preservation plan. Interest in repair and reformatting was significantly less than interest in preventive activities. The findings of this study suggest that assessment reports are thorough and organized; report content is consistent across the population studied. The study informs future assessments by defining current practice through the collection of concrete data on specific representative measures.

$\mathrm{O}$ ver the past quarter century, general preservation assessments have assisted organizations to understand factors that affect the long-term care of their collection. By evaluating policy, practice, facilities, and collections, preservation needs are determined and prioritized, and resources for implementation identified. ${ }^{1}$ The fundamental goal of the general assessment is to provide a fully inclusive review of current circumstances and projected risk, and, by doing so, assist a collecting institution in developing a preservation plan. ${ }^{2}$ The findings can help to reallocate existing resources, secure additional funding, raise awareness, and even define the extent of the preservation problem on a national scale. If the study method is reliable and institutional efforts at implementation are continuous, the outcome is a comprehensive preservation program that efficiently and effectively addresses risk in all areas of operation.

Since the late 1970s, authors, including Cunha, founder of the Northeast Document Conservation Center (NEDCC), have emphasized the study and understanding of preservation needs for libraries, museums, and archives. ${ }^{3}$ Tools and texts have been developed that together provide a reasonable paradigm to help ensure that a general assessment of preservation needs is complete and that the findings are practicable. ${ }^{4}$ However, most methods emphasize the survey process itself; little research has been conducted to identify actual outcomes associated with these assessments. Further, neither funding agents nor cultural institutions are collecting concrete data that accurately reflect the extent to which the goals of preservation programs are being achieved.

Uncoordinated, unplanned preservation activities can result in some areas

Karen E. K. Brown (kebrown@uamail. albany.edu) is Preservation Librarian, University at Albany (N.Y.) Libraries of need being overlooked. Sporadic efforts to protect collections may demonstrate an interest in preservation, yet without a strategy, resources likely will not 
be well-allocated, and long-term goals will not be achieved. The purpose of this study is twofold: to define current practice and to examine the use of general preservation assessments to determine what is being accomplished based on recommendations provided in the process. Based on data collected from 125 institutions in the United States, this research attempts to gauge the output of general assessments and the extent of preservation programs by examining the implementation of recommended actions.

This research seeks to answer the following questions:

- What types of institutions are conducting general preservation needs assessments?

- How much staff time is needed for the assessment and what are the major goals?

- What topics of concern are being considered?

- What is the content and structure of the report of findings?

This paper characterizes the assessment process and appraises key elements (topical coverage, phases of the study, report contents, and so on), providing a baseline for how the North American model of a general assessment is defined and undertaken. The data's value is to inform future assessments through the collection of concrete data on specific representative measures. The author plans a second paper, "Use of General Needs Assessments: Outputs," that will report what preservation actions are being realized as a result and characterize those attributes of the general assessment methodology that can be labeled as best practices. Factors that facilitate program success and reasons for limited development also will be explored.

\section{Literature Review Assessment Methods}

Three primary methods are used to study the problem of collection deterioration: general preservation assessments, collection condition surveys, and item-by-item surveys. ${ }^{5}$ The approaches are complementary, proceeding logically from the universal to the specific. Brief definitions of the three types of review provide a perspective on the use of the general preservation assessment process, which is the focus of this study.

The first method, the general preservation assessment, concentrates on the physical environment as well as on the activities, organizational policies, and resources that coalesce into an understanding of all the factors that can affect care of collections. While methods vary in their categorization of topics and the types and uses of data collected, they are typically broad in scope and include information about:
- the administration (mission, collecting policies, intellectual control, staffing/training needs, budgets);

- the building and facilities;

- environmental factors (monitoring and control of temperature, relative humidity, light, pollutants);

- protection against loss (pest management, emergency preparedness and prevention, security);

- the condition, storage, and handling of collections in various formats (including exhibition); and

- remedial treatment (reformatting, repair and conservation, library binding).

The review is intended to be general, although discrete groups of resources may be reviewed for evidence of damage to support identified risks or to recommend specific actions to reduce risk to that group as a whole. Follow-up reports are descriptive in style and emphasize damage prevention by identifying and controlling extrinsic agents of deterioration. This preventive approach is agreed to be central to preservation management because it benefits the collection as a whole and is more cost effective than remedial care. ${ }^{6}$ The purpose is not to quantify the scale of the problem, but rather to define need and initiate a planning process that will allow the institution to reduce risks to the collection and better allocate resources for preservation over time.

The second type of review is a statistical study referred to as a collection condition survey. It provides the next level of detail by gathering evidence of damage to the collection itself. By examining a representative sample of its holdings, an institution can predict the cost of action extrapolated to a larger population. Most library surveys that examined the problem of brittle and deteriorated paper in the 1980s were collection condition surveys, although they also testify to the importance of surveying collections more generally. ${ }^{7}$

The third approach, the item-by-item survey, is the most detailed. Its purpose is to provide data about each object under consideration in order to estimate the cost of remedial care on an individual basis and to plan for treatment. An item-level survey also may show which collections are the highest priority, and could include investigation into exact mechanisms of deterioration. ${ }^{8}$ Verifiable facts and figures reported from quantitative methods of examining library collections afford useful information and have proven effective in gaining administrative support and securing funding for preservation action. ${ }^{9}$

All three assessment types are valuable as tools for informing administration about their building environments, materials storage and handling, and collection condition and management, enabling them to develop a preservation program. The progression of study from the universal to specific ensures that overall risks have been addressed before expending significant resources on further study and remedial action. For example, like many funding agents, the 
New York State Library (NYSL) requires a general preservation assessment before applications for implementation through its Discretionary Grants Program will be considered. ${ }^{10}$ Others concur: "The general assessment . . . is now a basic requirement for institutions wishing to receive funds from many federal and private sources." 11 One can argue that preventive activities will extend the useful life of collections and that correcting external factors will reduce the sustained cost of repairing, reformatting, or replacing large numbers of material.

\section{General Assessment Attributes}

No single North American tool has been designed to study all types of cultural institutions. Because so many general and overlapping categories of review exist, exploring the development of assessment methods may be useful in order to develop a foundation for current practice.

One of the earliest references to the use of a general assessment is included in Planning for the Preservation of Library Materials, published by the Association of Research Libraries (ARL) in 1980. ${ }^{12}$ A copy of Cunha's report of a preservation survey at the University of Utah Libraries is included as an example of how outside consulting can provide the impetus for establishing a preservation program. ${ }^{13}$ Cunha authored What an Institution Can Do to Survey Its Conservation Needs, a tool that has seen multiple versions since it was first published by NYSL. ${ }^{14}$ The latest version, Assessing Preservation Needs: A Self-Survey Guide, is one of the most current self-survey tools available for use by small to medium-sized institutions to assess their own preservation needs. ${ }^{15}$ The guide also can assist professional consultants to help ensure the review is thorough and the information gathered is well-organized. Each topical section includes an introduction describing best practices followed by a worksheet with a series of questions that the institution attempts to answer to gauge its needs. This guidebook is not designed to address the needs of general circulating collections, focusing instead on historical collections in paper format.

Cunha points out that the survey is not a plan, but that it will help institutions identify risk, consider the value of items in the collection, develop recommendations for action, prioritize needs, and identify action steps: "The repository will then use these priorities, together with other relevant issues, such as available institutional resources and political considerations, to create a preservation plan that sets forth a specific schedule for accomplishing particular projects." 16

Patkus asserts that a systematic preservation program, or plan, ensures that scarce resources are used effectively, "and that important preservation activities are not neglected." 17 Patkus' work, while useful, suffers from a lack of information regarding implementation of findings. The brief section on preservation planning and implementation is limited to information previously presented by NEDCC. ${ }^{18}$

In the 1980s, ARL began a multifaceted, complex program to assist the organization and implementation of a preservation program by its members. ARL's Preservation Planning Program: An Assisted Self-Study Manual for Libraries, by Darling and Webster, and its accompanying Preservation Planning Program Resource Notebook are based on research conducted with support from the National Endowment for the Humanities for the design and testing of "a self-study procedure to enable academic libraries to identify and address preservation problems." ${ }^{\prime 19}$ As a basis for formal study, the process described is labor-intensive, suggesting that success in establishing a program is contingent on a significant investment of staff time. Completion can involve approximately two dozen people over a period of up to six months, as well as outside consultants to provide training and evaluation of progress (although the tool can be adapted by smaller libraries where a less formal or exhaustive approach is preferred). ${ }^{20}$ The Resource Notebook is a companion manual with further information drawn from the published literature.

Darling and Webster's outline of study activities forms the foundation of what can be expected in a general preservation assessment. These include preparing for the planning study and establishing the study framework (Phase I), determining preservation needs (Phase II), and planning the preservation program (Phase III). Identifying and documenting the library's preservation needs and the resources that might be employed to meet them is central to the investigation. Although much of the technical information is out of date, the general approach is comprehensive, reasonable, and still can assist with design of a preservation program.

In 1995, the Canadian Council of Archives published The Conservation Assessment Guide for Archives by Dalley. ${ }^{21}$ Unlike the NEDCC and ARL tools, this guide was designed for use by a trained conservator with qualifications in archival conservation, preservation planning, the nature of archives, and environmental systems. This text proposes standardized guidelines to assess the effect of policies, procedures, facilities, storage, environment, disaster management, and staff on the preservation of archival holdings. The author describes the assessment as "the first step of the preservation management process which integrates preventive conservation (preservation) into all archival activities." ${ }^{22}$ For example, the report guidelines prompt the evaluation of the institution's administration and how preservation and conservation has been considered in financing, long-range planning, mission statements, policies, arrangement and description, and so on. Dalley clearly delineates the responsibilities of the consultant and the institution for the process. Although designed for use in archival institutions, it can easily be adapted to study library collections. 
In the 1990s, two similar software applications were developed in an attempt to standardize a study method and compare findings across a defined population. Calipr was produced by the University of California at Berkeley to enable the California State Library to study statewide needs and develop the California Preservation Plan. ${ }^{23}$ Another version of Calipr, the PreNapp, was developed by the Research Libraries Group for its members as part of their Preservation Needs Assessment Package. ${ }^{24}$ These tools are used to produce reports about general needs based on a random sample of four hundred items from the collection itself. The programs are designed to generate recommendations to improve access (such as inventory control and staff education), housing (including emergency planning and environmental control), and condition (through rebinding, repair, use of enclosures, or reformatting). A combination of access and housing problems indicates exposure to risk, which, when coupled with condition, defines the level of risk based on these three factors. The preservation priority for collection materials is further determined by examining value. While useful, the programs alone cannot form the basis for long-term preservation planning; they require the institution to carry out further feasibility studies based on institutional technical and management capability and available resources. General recommendations for preservation action are generated, but no further information beyond a list of published resources is provided to assist implementation.

Emulating Calipr, efforts to assess preservation needs in the United Kingdom and Australia have focused on developing national preservation strategies that are based on aggregating identified needs in individual libraries, museums, and archives. The result has been the development of benchmark schemes that attempt to define levels of performance that can be compared among institutions. ${ }^{25}$ Bell and Lindsay contend that the North American general assessment is subjective, that the data collected cannot be used for comparative analysis between institutions, and that progress cannot be measured over time. ${ }^{26}$ The benchmark approach, on the other hand, was designed to define levels of performance as basic, good, and best practice, so that institutions, through self-study, can identify the strengths and weaknesses of collections care. Artlab Australia, with the History Trust of South Australia and the State Library of New South Wales, has recently published their efforts to study preservation needs at a state or national level. ${ }^{27}$ Their efforts are more far-reaching. They have worked to design a tool suitable to the broadest possible range of cultural institutions. The philosophy behind the tool suggests that use of a standard for risk assessment will lead to: (1) more transparent and accountable assessments; (2) a stronger emphasis on stakeholder consultation; and (3) more practical reports to help ensure responsible management by cultural caretakers, as well as equitable review by funding agents. ${ }^{28}$
General assessments of museums funded by the Institute of Museum and Library Services (IMLS) through their Conservation Assessment Program (CAP) in the United States differ from benchmark schemes in their emphasis on the individuality of the review, with less attention to aggregating data and more attention to specific actions that are required to reduce risk. The Conservation Assessment: A Tool for Planning, Implementing, and Fund-raising was first developed in 1988 to improve the usefulness of assessments by defining the parameters of a comprehensive survey. ${ }^{29}$ In 2002, a panel of CAP assessors worked together to try and define best practices for general assessments, reporting that although The Conservation Assessment, "provides a framework for the information CAP reports and site visits should cover, CAP assessors are not required to fit into a particular mold, nor is there an interest in standardizing reports."30 A later edition, version 9/99, The Conservation Assessment: A Proposed Model for Evaluating Museum Environmental Management Needs, was developed by the Getty Conservation Institute. ${ }^{31}$ Getty further emphasizes the individual nature of the study and the importance of understanding the institutional context to ensure that "broad strategies for environmental management . . . address the specific needs of the collection within the limitations of the climate, building, and institutional resources." ${ }^{32}$ It argues that the physical environment and organizational environment interact, and that outside expertise is required to make certain of the success of the study:

Past experience has shown that successful conservation assessments involve technical evaluations and critical judgments that go beyond the observation and documentation of the conditions manifested by the building or collections. Architectural and collections assessors rely on education, experience, skills, inquiry, deductive reasoning, collaboration and qualitative analysis to arrive at recommended strategies for environmental management. As might be expected, the analytical processes are highly individualistic and may even vary for the same professional when assessing different museums. ${ }^{33}$

In addition to IMLS, several funding agents in the United States provide substantial financial support to help organizations that are interested in preservation planning to undertake a general preservation assessment, including NYSL and the National Endowment for the Humanities. Application processes help to ensure that institutions are recognized nonprofit organizations with staff, a mission, and mandate; the collections have value and have been reasonably ordered and described; and efforts are being made to protect materials during storage and use. Funding agents also may favor applications in which recognized 
experts are committed to conducting the assessment. A self-survey also can result in a useful framework for coordinating preservation efforts. However, expertise, objectivity, and a degree of credibility may be lacking with the North American models. ${ }^{34}$ These shortcomings may limit the institution's ability to apply successfully for external funding to implement recommendations.

Many general preservation assessment models have been developed, described, adopted, and utilized to help institutions identify risks to their collections, propose and prioritize corrective actions, and assist with the development of practical plans. Most are useful in defining the responsibilities of the host institution and consultant, the scope of topics that should be reviewed, and how findings should be presented in a final report. Efforts have been made to standardize the study method, and assessors have discussed best practices, both in the United States and abroad. Interests in Australia and the United Kingdom have worked to define activities that represent best practices for preservation, or benchmarks of collections care. The popularity and persistence of several major funding initiatives, including the NYSL Discretionary Grants Program, the Preservation Assistants Grants offered by the National Endowment for the Humanities (NEH), and IMLS's CAP, suggests that general preservation assessments are valuable for guiding cultural institutions. However, few data define what is being undertaken or demonstrate its impact. No data correlate preservation activity to having conducted a baseline assessment, and no published information exists that quantitatively describes the effectiveness of general assessments. Based on the methods described in the literature, one must first define the typology of general assessments in order to later relate product with process.

\section{Study Method}

In fall 2003, questionnaires (see appendixes A and B) were mailed to 306 United States institutions that were identified as possibly having undertaken a general preservation assessment. Most of these institutions received public funding to support a preservation project, either through NYSL's Discretionary Grants Program or NEH's Preservation Assistance Grants program. Others were identified with support and assistance from NEDCC, which receives public funding to assist institutions with preservation surveys, training, and education. Those that had undertaken an assessment were asked to complete the questionnaire based on their most recent study (assuming the process could have been carried out more than once in the institution's history). The individual(s) most closely connected with the assessment process were asked to complete the questionnaire, consulting the survey report or other records to ensure the accuracy of their replies.
The survey instrument (see appendix) consisted of two parts. The first part provides a profile of the respondents and collects data about their goals and activities before and after the actual site visit, including how long after the site visit the institution was able to implement findings. It also asks about the involvement of the expert conducting the review, including time spent on site, what topics were considered, and follow-up services. The second part is a list of typical recommendations that might be given in a report of findings. Responding institutions were asked if each item had been recommended, and if so, whether or not that action was accomplished. Finally, participants were asked to identify conditions that might have hindered their ability to implement preservation recommendations, and to comment on how the assessment process could have been improved. Follow-up questionnaires were sent to respondents who did not return their questionnaires after six weeks.

In total, 188 questionnaires were returned (61.4 percent) with 36 institutions reporting that they had not had a general needs assessment, and 24 abstentions. Three questionnaires were deemed invalid, either because the institution was reporting on more than one study, thus confusing the results, or because entire pages of the form were left blank. The research results are therefore based on 125 completed questionnaires (40.9 percent). The respondents represent institutions in 29 states, including 102 located in the northeast (primarily Massachusetts and New York), 11 in the west and midwest, and 12 in the southern United States. The data from the questionnaires were analyzed using SPSS version 11.5.

\section{Results Who Are the Respondents?}

Of the responding institutions, 43 (34.4 percent) were colleges and universities (academic institutions), and 44 (35.2 percent) were public libraries. Of the remaining, 11 were museums, 8 were historical societies, 6 were archives, 2 were independent research libraries, and 11 were "other" (including 2 secondary school libraries, 2 government agencies, a nonprofit educational corporation, a theological seminary, and a "cultural institute"). These remaining participants (38 total, or 30.4 percent) are in some cases combined to facilitate statistical analysis of the data. For the purpose of comparison to peer institutions, categorization of institution type by primary function was preferred for this research as it helps to avoid confusion arising from signifying particular departments and units within colleges, universities, or other larger institutions. The types of institutions served by NEDCC, NYSL's Discretionary Grants program, and NEH Preservation Assistance Grants include those with research 
materials (libraries, archives, historical societies, and so on), as well as town and county records offices, and museums. The NEH guidelines about the types of institutions and collections that will be funded are much more broadly classified as "humanities" collections, and "may include special collections of books and journals, archives and manuscripts, prints and photographs, moving images, sound recordings, architectural and cartographic records, decorative and fine arts, textiles, archaeological and ethnographic artifacts, furniture, and historical objects." 35

Each institution defined its total institutional staff as an indicator of the size of the parent organization, scope of the collection, and scale of the general assessment. This indicator was chosen, as opposed to other options such as size of the collection, because comparing different types of collections is difficult. By using staff size as a measurement, one also may gauge the amount of time an institution can apply to the general assessment process and to the implementation of findings. Sixty-one institutions are relatively small, reporting 19 or fewer staff members. Thirty-nine institutions have between 20 and 69 staff; and 24 are relatively large, with more than 70 staff members. The greatest number of respondents (34, or 27.2 percent) has a staff size of 10 to 19 . Of those institutions with more than 100 staff members, 11 are academic. The data on staff size by type of institution are presented in table 1.
Participants estimated how much staff time they devote to preservation activities as an indicator of the level of institutional commitment and interest in preservation (see table 2). The majority, 64 (51.2 percent), reported less than 0.5 full-time equivalent (FTE) staff time devoted to preservation, followed closely by 31 (24.8 percent) of reporting institutions spending 0.5 to $0.9 \mathrm{FTE}$. Of 125 possible responses, only 15 (12.0 percent) indicated greater than 2.0 FTE. Of these, 9 had a total staff at their institutions of greater than 20 (7.2 percent of responses), and six had a total staff of less than 20 (4.8 percent of responses). A larger staff size did not equate with significantly more time being devoted to preservation activities.

Because many institutions were expected to be small or medium in size (this is a requirement when applying for Preservation Assistance Grants), the presence or absence of a preservation administrator was not chosen as an indicator of commitment to preservation, as hiring a full-time preservation officer generally is not feasible except in the largest institutions. In fact, Higginbotham and Wild have argued that a centralized program may not be the most effective means of administering a preservation program, and that preservation responsibilities should be part of the duties and responsibilities of all library personnel. ${ }^{36}$ However, respondents may have underestimated staff time invested in preservation. For example, the 2001-2002 ARL

Table 1. Respondent profile

\begin{tabular}{|c|c|c|c|c|c|c|c|c|c|c|}
\hline \multirow[b]{2}{*}{ Institution Type } & \multicolumn{2}{|c|}{ Response } & \multicolumn{6}{|c|}{ Staff Size } & \multirow[b]{2}{*}{$<5$} & \multirow[b]{2}{*}{ No Ans. } \\
\hline & No. & $\%$ & $>100$ & $70-100$ & $40-69$ & 20-39 & $10-19$ & $5-9$ & & \\
\hline Academic & 43 & 34.4 & 11 & 2 & 6 & 8 & 10 & 2 & 3 & 1 \\
\hline Public library & 44 & 35.2 & 4 & 2 & 5 & 11 & 16 & 3 & 3 & 0 \\
\hline Independent research library & 2 & 1.6 & 1 & 0 & 1 & 0 & 0 & 0 & 0 & 0 \\
\hline Archives & 6 & 4.8 & 0 & 0 & 0 & 2 & 1 & 2 & 1 & 0 \\
\hline Museum & 11 & 8.8 & 1 & 1 & 0 & 1 & 2 & 2 & 4 & 0 \\
\hline Historical society & 8 & 6.4 & 0 & 0 & 0 & 1 & 0 & 3 & 4 & 0 \\
\hline Other & 11 & 8.8 & 1 & 1 & 2 & 2 & 5 & 0 & 0 & 0 \\
\hline Total & 125 & - & 18 & 6 & 14 & 25 & 34 & 12 & 15 & 1 \\
\hline Total Percent & - & 100 & 14.4 & 4.8 & 11.2 & 20.0 & 27.2 & 9.6 & 12.0 & .8 \\
\hline
\end{tabular}

Table 2. Staff time devoted to preservation

\begin{tabular}{|c|c|c|c|c|c|c|c|c|}
\hline Staff Time for Preservation (FTE) & $>100$ & $70-100$ & 40-69 & $\begin{array}{c}\text { Staff Size } \\
20-39\end{array}$ & $10-19$ & $5-9$ & $<5$ & Total \\
\hline$>5.0$ & 1 & 1 & 0 & 1 & 0 & 0 & 0 & 3 \\
\hline $4.0-4.9$ & 2 & 0 & 0 & 1 & 0 & 0 & 0 & 3 \\
\hline $3.0-3.9$ & 2 & 0 & 0 & 1 & 0 & 1 & 1 & 5 \\
\hline $2.0-2.9$ & 0 & 0 & 0 & 0 & 1 & 1 & 2 & 4 \\
\hline $1.0-1.9$ & 2 & 0 & 2 & 3 & 3 & 2 & 0 & 12 \\
\hline $0.5-0.9$ & 4 & 0 & 4 & 8 & 10 & 0 & 5 & 31 \\
\hline$<0.5$ & 7 & 5 & 7 & 10 & 20 & 8 & 7 & 64 \\
\hline No answer & 0 & 0 & 0 & 0 & 0 & 0 & 0 & 3 \\
\hline Total & 18 & 6 & 13 & 24 & 34 & 12 & 15 & 125 \\
\hline
\end{tabular}


Preservation Statistics report that Group 4 ARL libraries (those with fewer than two million volumes) had a median 4.80 FTE staffing for preservation activities library wide. ${ }^{37}$ Also, the Oberlin Group was recently characterized as having a mean total of 2.0 FTE for library-wide preservation activities. ${ }^{38}$ Most of these institutions are libraries averaging collections of fewer than half a million volumes. ${ }^{39}$

Respondents were asked when each institution had undertaken their most recent general preservation assessment (see table 3). The purpose of dating the assessment is to try to determine the activities that are being accomplished over the long term, as well as those that are being accomplished in the period immediately following a review. The earliest date on the questionnaire is the first year that New York state began to provide financial support for general preservation assessments through its Discretionary Grants Program. Information provided by NEDCC listed their earliest assessment clients being served in 1993. NEH Preservation Assistance Grants were first awarded in 2000.

The distribution of responses favored those conducted between 2000 and 2003, with 72 (57.6 percent) surveys conducted during this period. Forty-nine assessments (39.2 percent) were undertaken between 1985 and 1999; four institutions did not answer the question. A cross tabulation of institution type by year of assessment shows that across institutional types, participation by public libraries has remained somewhat consistent, with 21 surveys reported before 1999, and 21 between 2000 and 2003. The period between 1995 and 1999 was a particularly active period for public libraries. General assessments by all other types of institutions combined have increased slightly, with 16 surveys reported before 1999, and 22 between 2000 and 2003. Participation by academic institutions increased steadily

Table 3. Year of most recent general assessment

\begin{tabular}{|c|c|c|c|c|c|c|c|c|}
\hline \multirow[b]{2}{*}{ Year of Assessment } & \multicolumn{2}{|c|}{ Response } & \multicolumn{2}{|c|}{ Academic Libraries } & \multicolumn{2}{|c|}{ Public Libraries } & \multicolumn{2}{|c|}{ Other } \\
\hline & No. & $\%$ & No. & $\%$ & No. & $\%$ & No. & $\%$ \\
\hline $1985-1989$ & 8 & 6.4 & 3 & 2.4 & 2 & 1.6 & 3 & 2.4 \\
\hline $1990-1994$ & 14 & 11.2 & 4 & 3.2 & 3 & 2.4 & 7 & 5.6 \\
\hline 1995-1999 & 27 & 21.6 & 5 & 4.0 & 16 & 12.8 & 6 & 4.8 \\
\hline 2000 & 21 & 16.8 & 7 & 5.6 & 7 & 5.6 & 7 & 5.6 \\
\hline 2001 & 21 & 16.8 & 8 & 6.4 & 8 & 6.4 & 5 & 4.0 \\
\hline 2002 & 23 & 18.4 & 13 & 10.4 & 3 & 2.4 & 7 & 5.6 \\
\hline 2003 & 7 & 5.6 & 1 & 0.8 & 3 & 2.4 & 3 & 2.4 \\
\hline No Answer & 4 & 3.2 & 2 & 1.6 & 2 & 1.6 & 0 & 0.0 \\
\hline Total & 125 & 100 & 43 & 34.4 & 44 & 35.2 & 38 & 30.4 \\
\hline
\end{tabular}

Table 4. Grant funding

\begin{tabular}{lcccccccc}
\hline & \multicolumn{2}{c}{ Response } & \multicolumn{2}{c}{ Academic Libraries } & \multicolumn{2}{c}{ Public Libraries } & \multicolumn{2}{c}{ Other } \\
Grant Funding Received & No. $\%$ & No. $\%$ & No. & $\%$ & No. & $\%$ \\
& 111 & 88.8 & 39 & 31.2 & 42 & 33.6 & 30 & 24.0 \\
\hline
\end{tabular}

between 1985 and 2002, and has more than doubled since 2000: only twelve were reported before 1999, and twentynine between 2000 and 2003.

Note that 88.8 percent of the institutions that participated in this research study reported receiving grant funding to pay for their general preservation assessment (see table 4). This was anticipated, as the mailing list was developed based on public reporting of funded activity identified through regional centers or public agents. The disproportionate number of assessments for colleges and universities may reflect the introduction of the NEH Preservation Assistance Grants program in 2000 and its emphasis on preservation of collections with significant value.

\section{The Assessment Process}

Questions 6 through 16 of the questionnaire attempted to determine if the assessment process and the topics considered meet the expectations outlined in the literature. The responsibility of the host institution and surveyor, stages of the review, and comprehensiveness of the assessment were examined.

Respondents were asked to estimate the time spent by their institution preparing for the review in advance of the site visit (see table 5). Activities could include committee time, application or contract preparation, and so on, and relate to Darling and Webster's first phase of the survey process: preparation for the planning study and establishing the study framework. Overall, 92 (73.6 percent) spent 40 hours or less. Only 13 (10.4 percent) institutions spent 41 or more hours. The data, sorted for analysis according to type of institution, indicate no apparent trends. Colleges and universities represent 7 of the 13 institutions reporting 41 to 100 hours preparing for the site visit.

The amount of time spent preparing for the site visit is less than 41 hours for the majority of institutions. Groundwork through the completion of presurvey is less than anticipated. Eighty respondents (64.0 percent) completed a questionnaire in advance of the site visit (see table 5). Completion of a pre-survey questionnaire is described in most methods: it helps assessors to focus on key areas and use their time on site to its best advantage. Completion of some questionnaires may demand a substantial amount of staff time, effectively involving the institution through self-study. ${ }^{40}$

The data were analyzed to discover if any relationship existed 
Table 5. Preparation and planning for assessment

\begin{tabular}{|c|c|c|c|c|c|c|c|c|}
\hline \multirow[t]{2}{*}{$\begin{array}{l}\text { Preparation } \\
\text { Time/hours }\end{array}$} & \multicolumn{2}{|c|}{ Response } & \multicolumn{2}{|c|}{ Academic Libraries } & \multicolumn{2}{|c|}{ Public Libraries } & \multicolumn{2}{|c|}{ Other } \\
\hline & No. & $\%$ & No. & $\%$ & No. & $\%$ & No. & $\%$ \\
\hline$<20$ & 47 & 37.6 & 14 & 11.2 & 18 & 14.4 & 15 & 12.0 \\
\hline $20-40$ & 45 & 36.0 & 16 & 12.8 & 16 & 12.8 & 13 & 10.4 \\
\hline $41-100$ & 13 & 10.4 & 7 & 5.6 & 4 & 3.2 & 2 & 1.6 \\
\hline Do not know & 19 & 15.2 & 5 & 4.0 & 6 & 4.8 & 8 & 6.4 \\
\hline No answer & 1 & 0.8 & 1 & 0.8 & 0 & 0.0 & 0 & 0.0 \\
\hline Total & 125 & 100 & 43 & 34.4 & 44 & 35.2 & 38 & 30.4 \\
\hline \multicolumn{9}{|c|}{$\begin{array}{l}\text { Pre-Survey } \\
\text { Questionnaire } \\
\text { Completed }\end{array}$} \\
\hline Yes & 80 & 64.0 & 26 & 20.8 & 31 & 24.8 & 23 & 18.4 \\
\hline No & 17 & 13.6 & 11 & 8.8 & 4 & 3.2 & 2 & 1.6 \\
\hline Do not know & 27 & 21.6 & 5 & 4.0 & 9 & 7.2 & 13 & 10.4 \\
\hline No answer & 1 & 0.8 & 1 & 0.8 & 0 & 0.0 & 0 & 0.0 \\
\hline Total & 125 & 100.0 & 43 & 34.4 & 44 & 35.2 & 38 & 30.4 \\
\hline
\end{tabular}

Table 6. Pre-site visit preparation time by staff size

\begin{tabular}{|c|c|c|c|c|c|c|c|c|}
\hline Preparation Time/Hours & $>100$ & $70-100$ & $40-69$ & $\begin{array}{c}\text { No. of Staf } \\
20-39\end{array}$ & $10-19$ & $5-9$ & $<5$ & Total \\
\hline$<20$ & 7 & 1 & 5 & 8 & 15 & 5 & 6 & 47 \\
\hline $20-40$ & 4 & 4 & 5 & 13 & 8 & 3 & 7 & 44 \\
\hline $41-100$ & 0 & 1 & 2 & 3 & 6 & 0 & 1 & 13 \\
\hline Do not know & 6 & 0 & 2 & 1 & 5 & 4 & 1 & 19 \\
\hline No answer & 0 & 0 & 0 & 0 & 0 & 0 & 0 & 2 \\
\hline Total & 17 & 6 & 14 & 25 & 34 & 12 & 15 & 125 \\
\hline
\end{tabular}

between the total number of institutional staff and the amount of time spent preparing for the survey (see table 6). Of those with a staff size of 19 or fewer (61), 26 reported spending less than 20 hours, 18 reported spending twenty to 40 hours, and 7 reported spending 41 to 100 hours preparing for the study. For those institutions with a staff size of more than 20 and less than 100 (45), 14 reported spending less than 20 hours, 22 reported spending 20 to 40 hours, and 6 reported 41 to 100 hours; 3 did not know how much staff time was spent in preparation. Of the responding institutions with more than 100 staff, none reported 40 to 100 hours of preparation time. This finding is somewhat remarkable, since one might assume the largest institutions would correlate to a greater amount of time preparing for the assessment.

Most institutions enter into the assessment process with a series of goals for undertaking the study. An understanding of the purpose and potential scope of a general preservation assessment may be assumed from an examination of the major goals cited for undertaking the review. Further analysis of outputs may indicate the extent to which the general assessment contributes to achieving these goals. Respondents were asked to select those goals that applied to their institution. Fourteen were listed in the questionnaire, and the number of goals per institution was calculated. The mean number of goals per institution was 5.49, indicating that less than half of the topics listed were of interest to most of the respondents. The goals most frequently selected from the list were to: (1) develop a preservation plan (77.6 percent of respondents); (2) improve storage practices (76.0 percent); and (3) improve the environment (65.6 percent). Improving the facility (56.8 percent of respondents), increasing staff awareness of preservation (54.4 percent), and increasing administrative support (52.8 percent) also were important to most institutions surveyed. Advancing repair activities (27.2 percent of respondents) was not the topic of least interest, but it still rated lower than goals associated with prevention and administrative oversight. The topics of least interest were to: (1) increase staffing for preservation (18.4 percent of respondents); (2) advance reformatting activity (to what format was not specified; 15.2 percent); (3) improve exhibition practices (12.0 percent); and (4) other (8.8 percent). Only 4 institutions reported not knowing what their goals were in undertaking the assessment process. The very low response to the category "Other" indicates that the choices 
listed covered most areas of concern. These findings are summarized in table 7 .

Major goals for undertaking a general preservation assessment were analyzed according to the type of institution (see table 7), with only two apparent trends. The data indicate that of the most frequently selected goals, interest was slightly less among the combined group (20.0 percent), as compared to public libraries (29.6 percent) or colleges and universities (28.0 percent), in developing a preservation plan. Of the topics generating the least interest, 7 of the 19 respondents interested in reformatting are "others," 8 are public libraries, and only 4 are academic. The data suggest that most institutions were concerned with administrative and overall, preventive activities that benefit the collection as a whole, as opposed to remedial care. However, the low mean indicates that perhaps many institutions were not fully aware of, or interested in, the range of issues that might be considered during a general assessment. With the possible exception of "improving exhibition practice," the goals listed should be covered in most general preservation assessments. The expert conducting the assessment may judge, at its conclusion, whether goals have been met or not. He or she also may be able to help the institution to reconsider its goals and objectives through the report of findings.

The second phase of the general assessment, determining preservation needs, includes a scheduled site visit that should allow sufficient time to explore the full range of issues relevant to the institution at hand. The questionnaire asked the respondents to characterize the expert that conducted the assessment. Of 125 responses, 121 (96.8 percent) engaged an outside assessor; 2 engaged a staff member (1.6

Table 7. Major goals of the assessment by type of respondent

\begin{tabular}{|c|c|c|c|c|c|c|c|c|c|}
\hline \multirow[b]{3}{*}{ Goal } & \multicolumn{7}{|c|}{ "Yes" Response } & & \\
\hline & \multicolumn{2}{|c|}{ Total } & \multicolumn{2}{|c|}{ Academic Libraries } & \multicolumn{2}{|c|}{ Public Libraries } & & \multicolumn{2}{|c|}{ Other } \\
\hline & No. & $\%$ & No. & $\%$ & No. & $\%$ & & No. & $\%$ \\
\hline Develop a preservation plan & 97 & 77.6 & 35 & 28.0 & 37 & 29.6 & & 25 & 20.0 \\
\hline Improve storage practices & 95 & 76.0 & 32 & 25.6 & 33 & 26.4 & & 30 & 24.0 \\
\hline Improve the environment & 82 & 65.6 & 28 & 22.4 & 28 & 22.4 & & 26 & 20.8 \\
\hline Improve the facility & 71 & 56.8 & 24 & 19.2 & 27 & 21.6 & & 20 & 16.0 \\
\hline Increase staff awareness of preservation & 68 & 54.4 & 29 & 23.2 & 20 & 16.0 & & 19 & 15.2 \\
\hline Increase administrative support & 66 & 52.8 & 25 & 20.0 & 23 & 18.4 & & 18 & 14.4 \\
\hline Improve security & 46 & 36.8 & 15 & 12.0 & 16 & 12.8 & & 15 & 12.0 \\
\hline Increase preservation budget & 36 & 28.8 & 13 & 10.4 & 10 & 8.0 & & 13 & 10.4 \\
\hline Advance repair activity & 34 & 27.2 & 15 & 12.0 & 10 & 8.0 & & 9 & 7.2 \\
\hline Improve pest management & 28 & 22.4 & 13 & 10.4 & 5 & 4.0 & & 10 & 8.0 \\
\hline Increase preservation staffing & 23 & 18.4 & 11 & 8.8 & 5 & 4.0 & & 7 & 5.6 \\
\hline Advance reformatting activity & 19 & 15.2 & 4 & 3.2 & 8 & 6.4 & & 7 & 5.6 \\
\hline Improve exhibition practices & 15 & 12.0 & 3 & 2.4 & 6 & 4.8 & & 6 & 4.8 \\
\hline Other & 11 & 8.8 & 5 & 4.0 & 2 & 1.6 & & 4 & 3.2 \\
\hline Do not know & 4 & 3.2 & 0 & 0.0 & 2 & 1.6 & & 2 & 1.6 \\
\hline \multicolumn{10}{|l|}{ Mean: 5.49} \\
\hline \multicolumn{10}{|c|}{ Table 8. Time spent and adequate time for site visit by staff size } \\
\hline & \multicolumn{4}{|c|}{ Response } & \multicolumn{3}{|c|}{ Staff Size } & & \\
\hline Time for Site Visit & No. & $\%$ & $>100$ & $70-100$ & 40-69 & $20-39$ & $10-19$ & $5-9$ & $<5$ \\
\hline$<1$ day & 11 & 8.8 & 2 & 1 & 1 & 2 & 1 & 2 & 2 \\
\hline 1 day & 60 & 48.0 & 10 & 3 & 6 & 9 & 19 & 3 & 10 \\
\hline 2 days & 37 & 29.6 & 5 & 1 & 6 & 8 & 9 & 5 & 3 \\
\hline $3-5$ days & 11 & 8.8 & 1 & 1 & 1 & 5 & 2 & 1 & 0 \\
\hline Other & 2 & 1.6 & 0 & 0 & 0 & 1 & 1 & 0 & 0 \\
\hline Missing & 4 & 3.2 & & & & & & & \\
\hline \multicolumn{10}{|l|}{ Adequate Time for Visit } \\
\hline Yes & 98 & 78.4 & 13 & 6 & 10 & 21 & 27 & 9 & 12 \\
\hline Too much & 1 & 0.8 & 0 & 0 & 0 & 0 & 1 & 0 & 0 \\
\hline Too little & 13 & 10.4 & 2 & 0 & 3 & 4 & 2 & 0 & 2 \\
\hline Do not know & 11 & 8.8 & 3 & 0 & 0 & 0 & 4 & 3 & 1 \\
\hline Missing & 2 & 1.6 & & & & & & & \\
\hline
\end{tabular}


percent), 1 did not know, and 1 respondent did not answer the question ( 0.8 percent). These results are not surprising; the population was derived primarily from sources that support and encourage the use of outside expertise.

The length of time allowed for the site visit was considered in this study (see table 8). The greatest number of respondents (60, or 48.0 percent) reported their site visits lasted 1 day; 37 (29.6 percent) had site visits that lasted for 2 days. Respondents also were asked to report if enough time was allowed to conduct the site visit properly. The majority (98, or 78.4 percent) reported that the time taken for site reviews was adequate. Only 13 respondents (10.4 percent) thought that too little time was allowed for the site visit. Most granting agencies limit the amount they will fund for consulting services, depending on the scope of the project. For example, NYSL will fund a consultant for only 3 to 4 days, including report writing, unless compelling arguments for greater support are presented. The data indicate that current awards are adequate for the majority of assessments. No conclusions can be drawn by comparing staff size to the data about adequate time for the site visit.

Respondents were asked to identify the topics or issues their assessment considered (see table 9). The purpose of this question was to provide support for the analysis by determining that the population under review had, in fact, undertaken a general review. The mean number of topics considered per institution was 6.54. Environmental factors were the most frequently selected subject, covered in 96.0 percent, or 120 out of 125 assessments. The second most frequently considered topic was the condition of the general collection (87.2 percent), followed closely by collection management (77.6 percent). A majority of respondents reported that the condition of their special collection was considered (68.8 percent), as well as security (68.0 percent), emergency management (66.4 percent), access and use (65.6 percent), and the organizational context for the review (55.2 percent). Staff training needs was reported by slightly less than half of the institutions responding (45.6 percent).

Bibliographic control was the topic least considered but

Table 10. Report components was still included in many of the surveys (27.2 percent of respondents), suggesting that assistance with cataloging and classification is often required. Of the 34 institutions reporting that bibliographic control was considered, 14 (11.2 percent) were "other" institutions, slightly higher than what was reported by colleges/universities (9 respondents) and public libraries (11 respondents). Both NYSL's Discretionary Grants Program and NEH's Preservation Assistance Grants include bibliographic control as one of the activities that could be part of a general preservation assessment. ${ }^{41}$ Bibliographic control, usually considered a pre-requisite for conducting the general assessment to help ensure the client knows what is in the collection, is sometimes identified as a need to assist managing preservation of the collection. By extension, those contracting for a general assessment should consider hiring a consultant familiar with bibliographic methods appropriate to their institution.

The elements of the assessment report (executive summary, background information, appendixes, and so on) should indicate how well the findings are presented by the consultant for use by the client. A high majority of respondents reported that most of the components listed

Table 9. Topics/issues considered by type of institution

\begin{tabular}{|c|c|c|c|c|c|c|c|c|}
\hline \multirow[b]{2}{*}{ The Assessment Considered } & \multicolumn{2}{|c|}{ Total } & \multicolumn{2}{|c|}{ “Yes" Response } & \multicolumn{2}{|c|}{ Public Libraries } & \multicolumn{2}{|c|}{ Other } \\
\hline & No. & $\%$ & No. & $\%$ & No. & $\%$ & No. & $\%$ \\
\hline Environmental factors & 120 & 96.0 & 40 & 32.0 & 44 & 35.2 & 36 & 28.8 \\
\hline General condition of the collection & 109 & 87.2 & 37 & 29.6 & 37 & 29.6 & 35 & 28.0 \\
\hline Collections management & 97 & 77.6 & 32 & 25.6 & 34 & 27.2 & 31 & 24.8 \\
\hline Condition of special collection & 87 & 68.8 & 31 & 24.8 & 35 & 28.0 & 21 & 16.8 \\
\hline Security & 85 & 68.0 & 28 & 22.4 & 35 & 28.0 & 22 & 17.6 \\
\hline Emergency management & 83 & 66.4 & 31 & 24.8 & 30 & 24.0 & 22 & 17.6 \\
\hline Access and use & 82 & 65.6 & 27 & 21.6 & 33 & 26.4 & 22 & 17.6 \\
\hline Organizational context & 69 & 55.2 & 28 & 22.4 & 21 & 16.8 & 20 & 16.0 \\
\hline Training needs & 57 & 45.6 & 26 & 20.8 & 15 & 12.0 & 16 & 12.8 \\
\hline $\begin{array}{l}\text { Bibliographic control } \\
\text { Mean: } 6.54\end{array}$ & 34 & 27.2 & 9 & 7.2 & 11 & 8.8 & 14 & 11.2 \\
\hline
\end{tabular}

\section{What was included in the report?}

List of recommended preservation action organized by priority

Observations from the site visit organized by preservation topic

Executive summary

Information to achieve the required preservation actions

Background information on preservation topics

Appendices with further resources

Other

Do not know

No report was issued

Mean: 4.48

$\begin{array}{rc}\text { "Yes" } & \text { Response } \\ \text { No. } & \% \\ 109 & 87.2 \\ 108 & 86.4 \\ 100 & 80.0 \\ 88 & 70.4 \\ 81 & 64.8 \\ 77 & 61.6 \\ 2 & 1.6 \\ 1 & .8 \\ 1 & .8\end{array}$


were included with their report (see table 10). The most frequently cited section is a list of preservation actions organized by priority, reported by 109 of 125 institutions (87.2 percent). Most institutions reported that the observations from the site visit were ordered by preservation topic (108, or 86.4 percent); the report included an executive summary ( 80.0 percent); they received the information needed to achieve a preservation action (70.4 percent); background information was provided (64.8 percent); and the report contained appendixes with further resources (61.6 percent). The data indicate that the components of a final report were consistent across the population studied; only 2 institutions selected "Other" to compensate for components not listed. Only 1 institution reported not receiving a report, and only 1 did not know the contents of the report.

Respondents were asked to report on the types of follow-up services they received after the site visit (see table 11). Only 50.4 percent of institutions discussed the findings with their consultant before their report was submitted, and fewer than half (43.2 percent) reported that their consultant inquired if they had any corrections or concerns. However, 36.8 percent reported that the assessor responded to requests for further information, and 46.4 percent discussed implementation strategies. After the site visit, 32.0 percent of assessors gave an oral report of findings. The mean number of follow-up services per institutions was 2.40. Only 7 institutions reported no follow-up services after their site visit.

While a report of findings may be well-prepared, this alone does not indicate how well-considered the preservation actions are in the context of the institution under review. The consultant should discuss findings before submitting a written report, or submit the written report in draft form for review by the host (and other participating consulting specialists), and make revisions before considering the report final. ${ }^{42}$ CAP assessors, in presentations given in June 2002, suggested that a correlation exists between successful program development and a positive working relationship with the consultant. ${ }^{43} \mathrm{~A}$ few written comments submitted by volunteers that participated in this study highlighted the need for more discussion with the surveyor before, during, and after their report was submitted. In addition, 4 institutions cited the lag time between the site visit and delivery of the written report as unsatisfactory and longer than anticipated. Overall, this study suggests that collaborative analysis and strategizing between host institution and assessor was weaker than anticipated. Further investigation into this phase of the assessment process may be warranted.

To finalize the characterization of the assessment process, participating institutions were asked to report how much staff time was spent reviewing the findings of their report (see table 12). The majority of institutions spent 40 hours or less on the review, with 56 institutions (44.8 percent) spending fewer than 20 hours, and 41 institutions (32.8 percent) spending 21 through 40 hours. Only 7 institutions reported spending 41 hours or more, and 18 reported that they did not know how much time was spent. No significant trends were noted by institution type or staff size. These data indicate that most institutions invest one week or less of staff time reviewing the final report of their assessment. This figure seems low, although it is comparable to the time spent in advance of the site visit (see table 5). The findings of this study are a good indicator of the amount of time most institutions can expect to spend when undertaking a general assessment. Most published resources have been less clear about the amount of time it will take to conduct an assessment, stating that it is dependent on the size and type of institution participating, among other factors. ${ }^{44}$
Table 11. Follow-up services

\begin{tabular}{lccccc}
\hline & \multicolumn{2}{c}{ Yes } & \multicolumn{2}{c}{ No } \\
After the site visit, the assessor & No. & \multicolumn{1}{c}{$\%$} & No. & $\%$ \\
Discussed recommendations before submitting a report & 63 & 50.4 & 62 & 49.6 \\
Discussed implementation strategies & 58 & 46.4 & 67 & 53.6 \\
Inquired if there were corrections, concerns, etc. & 54 & 43.2 & 71 & 56.8 \\
Responded to questions for further information & 46 & 36.8 & 79 & 63.2 \\
Delivered an oral report of findings & 40 & 32.0 & 85 & 68.0 \\
Requested your evaluation of the assessment & 37 & 29.6 & 88 & 70.4 \\
Do not know & 17 & 13.6 & 108 & 86.4 \\
Provided no follow up services & 7 & 5.5 & 118 & 94.4 \\
Other & 4 & 2.3 & 121 & 96.8 \\
Mean: 2.40 & & & & & \\
& & & & & \\
\hline
\end{tabular}

Table 12. Staff time reviewing findings by staff size

\begin{tabular}{|c|c|c|c|c|c|c|c|c|}
\hline \multirow{2}{*}{\multicolumn{2}{|c|}{ Review Time/hours $>100$}} & \multirow[b]{2}{*}{$70-100$} & \multirow[b]{2}{*}{$40-69$} & \multirow[b]{2}{*}{ 20-39 } & \multicolumn{2}{|c|}{ Staff Size } & \multirow[b]{2}{*}{$<5$} & \multirow{3}{*}{$\begin{array}{c}\text { Total } \\
56\end{array}$} \\
\hline & & & & & $10-19$ & $5-9$ & & \\
\hline$<20$ & 9 & 3 & 7 & 12 & 15 & 5 & 5 & \\
\hline $21-40$ & 3 & 2 & 4 & 10 & 13 & 2 & 7 & 41 \\
\hline $41-100$ & 0 & 0 & 1 & 1 & 0 & 1 & 2 & 5 \\
\hline $100+$ & 0 & 0 & 0 & 1 & 1 & 0 & 0 & 2 \\
\hline Do not know & 6 & 0 & 2 & 1 & 5 & 3 & 1 & 18 \\
\hline No answer & & & & & & & & 3 \\
\hline Total & 18 & 5 & 14 & 25 & 34 & 11 & 15 & 125 \\
\hline
\end{tabular}




\section{Conclusion}

This paper characterizes the assessment process and appraises key elements, providing a foundation that defines preservation reviews that have been undertaken since the late 1980s by a range of United States institutions, primarily colleges and universities, and public libraries. The value of this data is that it informs future assessments through the collection of concrete data on representative measures that could stand for the whole. Of the institutions that participated in this study, most are small or medium in size and received funding to hire an outside expert to conduct their review. The time invested by the host institution in preparation for the assessment, and in reviewing the findings of the subsequent report, is less than two full weeks in staff time per institution. Most assessments are broad in scope and favor the study of preventive activities. The largest part of cited goals were to develop a preservation plan, improve storage practices, and to improve the environment. The time allowed for site visits is adequate in the majority of cases, and the report content is consistent across the population studied. A review of follow-up services suggests that collaborative analysis and strategic planning with the assessor is weak. Further investigation into the role of the consultant, especially during report preparation and after its delivery, is warranted. A second paper, "Use of General Needs Assessments: Outputs," planned by this author, will report what preservation actions are being realized as a result of the process. In addition, the paper will try to characterize those attributes of the general assessment methodology that can be labeled as best practices.

\section{References and Notes}

1. Sherelyn Ogden, "What is Preservation Planning?," in Preservation of Library \& Archival Materials, ed. Sherelyn Ogden, 3d ed. (Andover, Mass.: Northeast Document Conservation Center, 1999).

2. Jutta Reed-Scott, "Planning for Preservation in Libraries," in Preservation Issues and Planning, 82-96, ed. Paul N. Banks and Roberta Pilette (Chicago: ALA, 2000).

3. Examples include: George M. Cunha, What An Institution Can Do to Survey Its Conservation Needs (New York: New York Library Association, 1979); Mary Lynn Ritzenthaler, Archives \& Manuscripts: Conservation (Chicago: Society of American Archivists, 1983); Carolyn L. Rose and Catharine A. Hawks, "A Preventive Conservation Approach to the Storage of Collections," in Storage of Natural History Collections: A Preventive Conservation Approach, 1-20, ed. Carolyn L. Rose, Catharine A. Hawks, and Hugh H. Genoways, vol. 1 (Iowa City, Iowa: Society for the Preservation of Natural History Collections, 1995).

4. Pamela W. Darling and Duane E. Webster, Preservation Planning Program: An Assisted Self-Study Manual for Libraries, expanded ed. (Washington, D.C.: Association of Research
Libraries, Office of Management Studies, 1987); Jane Dalley, The Conservation Assessment Guide for Archives (Ottawa, ON: Canadian Council of Archives, 1995); Barclay Ogden and Maralyn Jones, Calipr, Version 3.0xp (Sacramento: California State Library, 1997); Beth Patkus, Assessing Preservation Needs: A Self-Survey Guide (Andover, Mass.: Northeast Document Conservation Center, 2003).

5. Graham Matthews, "Surveying Collections: The Importance of Condition Assessment for Preservation Management," Journal of Librarianship and Information Science 27, no. 4 (1995): 227-36. While use of the terminology differs, the definitions applied in this study closely relate to those used in the published literature. Matthews provides an interesting review on preservation surveying, including an overview of the problem with consistent use of proper terms.

6. George Cunha, Methods of Evaluation to Determine the Preservation Needs in Libraries and Archives: A RAMP Study with Guidelines (Paris: UNESCO, General Information Programme and UNISIST, 1988); Margaret Child, "Preservation Assessment and Planning," in Preservation of Library \& Archival Materials: A Manual, 5-11, ed. Sherelyn Ogden (Andover, Mass.: Northeast Document Conservation Center, 1999), 8-9.

7. Gay Walker et al., "The Yale Survey: A Large-Scale Study of Book Deterioration in the Yale University Library," College \& Research Libraries 46, no. 2 (1985): 111-32; Tina Chrzastowski et al., "Library Collection Deterioration: A Study at the University of Illinois at Urbana-Champaign," College d Research Libraries 50, no. 5 (1989): 577-84; Anne L. Reynolds, Nancy C. Schrock, and Joanna Walsh, "Preservation: The Public Library Response," Library Journal 15 (1989): 128-32.

8. Suzanne Keene, "Audits of Care: A Framework for Collections Condition Surveys," in Care of Collections, ed. Simon Knell (New York: Routledge, 1994).

9. Thomas H. Teper and Stephanie Atkins, "Building Preservation: The University of Illinois at Urbana-Champaign's Stacks Assessment," College \& Research Libraries 64, no. 3 (2003): 211-27. This is one of the most current published reports of the successful uses of general assessments and collection condition surveys.

10. New York State Education Department, The New York State Program for the Conservation and Preservation of Library Research Materials, Discretionary Grant Guidelines and Application 2004-2005 (Albany, N.Y.: The University of the State of New York, The State Education Department, The New York State Library, Division of Library Development, 2004).

11. Heritage Preservation and the Getty Conservation Institute, The Conservation Assessment: A Tool for Planning, Implementing, and Fund-raising (Washington, D.C.: Heritage Preservation, 1991), 1.

12. Association of Research Libraries, Planning for the Preservation of Library Materials, SPEC Kit 66 (Washington, D.C.: ARL, Office of Management Studies, 1980).

13. George Cunha, "A Report of a Survey at the University of Utah Libraries, 3 October 1977," in Planning for the Preservation of Library Materials, SPEC Kit 66 (Washington, 
D.C.: Association of Research Libraries, Office of Management Studies, 1980), 28-37.

14. George Cuhna, Howard Lowell, and Robert Schnare Jr., Conservation Survey Manual (New York: Section on the Management of Information Resources and Technology of the New York Library Association, 1982); Cunha, Methods of Evaluation; Karen Motylewski, What an Institution Can Do to Survey Its Own Preservation Needs (Andover, Mass.: Northeast Document Conservation Center, 1991); Patkus, Assessing Preservation Needs.

15. Patkus, Assessing Preservation Needs.

16. Ibid., 20

17. Ibid., 1.

18. Sherelyn Ogden, Preservation Planning: Guidelines for Writing a Long-Range Plan (Washington, D.C.: American Association of Museums, 1997).

19. Pamela W. Darling and Duane E. Webster, Preservation Planning Program: An Assisted Self-Study Manual for Libraries (Washington, D.C.: Association of Research Libraries, Office of Management Studies, 1982), i-iii; Pamela W. Darling, comp., Wesley Boomgaarden, ed., Preservation Planning Program: Resource Notebook (Washington, D.C.: Association of Research Libraries, Office of Management Studies, 1987).

20. Darling and Webster, Preservation Planning Program, iii.

21. Dalley, The Conservation Assessment Guide.

22. Ibid., 9 .

23. California State Library, The California Preservation Program (Sacramento, Calif.: 1995). Accessed May 26, 2004, http://cpc.stanford.edu/library/calpresprog; Barclay Odgen and Maralyn Jones, Calipr: An Automated Preservation Needs Assessment Instrument Created for California Libraries, June 1997; (Sacramento, Calif.: California State Library, 1997). Accessed Oct. 25, 2004, http://sunsite. berkeley.edu/CALIPR/documentation.html.

24. The Research Libraries Group, Guide to the RLG Preservation Needs Assessment Package_Print Materials (Mountain View, Calif.: The Research Libraries Group, Inc., 1993).

25. The Council for Museums, Archives and Libraries, Benchmarks in Collection Care for Museums, Archives and Libraries (London: Resource, 2002).

26. Nancy Bell and Helen Lindsay, Benchmarks in Collections Care for UK Libraries, Library and Information Research Report 55 (London: Library and Information Commission, 2000), 25.

27. Heritage Collections Council, Development of a Best Practice Model for Conservation and Preservation Assessment Plans for Cultural Collections, Final Project Report, vol. 1:
Methodology and Analysis. Accessed May 25, 2004, http:// sector.amol.org.au/_data/page/147/best_practice_voll. pdf; Heritage Collections Council, A Best Practice Model for Conservation and Preservation Assessment Plans for Cultural Collections, vol. 2. Accessed May 25, 2004, http:// sector.amol.org.au/_data/page/147/best_practice_vol1.pdf.

28. Heritage Collections Council, Development of a Best Practice Model.

29. Heritage Preservation and the Getty Conservation Institute, The Conservation Assessment.

30. Heritage Preservation, Best Practices for General Conservation Assessments, 2002. Accessed June 1, 2004, www. heritagepreservation.org/PDFS/BestPractices.pdf.

31. Getty Conservation Institute, The Conservation Assessment: A Proposed Model for Evaluating Museum Environmental Management Needs, version 9/99 (Los Angeles: Getty Conservation Institute, 1998).

32. Getty Conservation Institute, The Conservation Assessment: A Proposed Model, 7.

33. Ibid., 3-4.

34. Ogden, Preservation Planning: Guidelines, APX1-2.

35. National Endowment for the Humanities, Grant Programs: Preservation Assistance Grants. Accessed June 10, 2004 , www.neh.gov/grants/guidelines/pag.html.

36. Barbra Buckner Higginbotham and Judith W. Wild, The Preservation Program Blueprint (Chicago: ALA, 2001).

37. Association of Research Libraries, ARL Preservation Statistics 2001-02, comp. and ed. Mark Young and Martha Kyrillidou (Washington, D.C.: ARL, 2003).

38. Anne R. Kenney and Deirdre C. Stam, The State of Preservation Programs in American College and Research Libraries: Building a Common Understanding and Action Agenda, CLIR Report no. 111 (Washington, D.C.: Council on Library and Information Resources, 2002). Accessed Dec. 27, 2004, www.clir.org/pubs/reports/pub111/contents. html.

39. Ibid

40. Heritage Preservation and the Getty Conservation Institute, The Conservation Assessment.

41. National Endowment for the Humanities, Grant Guidelines: Preservation Assistance Grants; New York State Education Department, The New York State Program for the Conservation and Preservation of Library Research Materials, 9.

42. Dalley, The Conservation Assessment Guide; Heritage Preservation, Best Practices.

43. Heritage Preservation, Best Practices.

44. Dalley, The Conservation Assessment Guide.

\section{Appendix. Questionnaire: Use of General Preservation Assessments (Part I)}

Please answer each question to the best of your ability. You may choose not to answer any question(s) you do not wish to. Please leave these questions blank.

I PREFER NOT TO PARTICIPATE IN THIS STUDY $\square$

\section{MY INSTITUTION HAS NOT HAD A GENERAL PRESERVATION ASSESSMENT $\square$}

If you checked either of the boxes above please return the questionnaire now. Thank you. 


\section{Part I: The General Preservation Assessment Process}

1. Which of the following most closely defines your institution? Check one

$\square$ College or university $\square$ Public library $\square$ Independent research library $\quad \square$ Archives $\square$ Museum

$\square$ Historical society

$\square$ Other (please describe):

2. What is the total number of your institutional staff?
$\square>100$
$70-100$
$40-69$
$\square 20-39$
$10-19$
$5-9$
$<5$

3. How much staff time is devoted to preservation activities?
$\square$ More than 5.0 FTE
$\square 4.0-5.0$ FTE $\square 3.0-3.9$ FTE
$2.0-2.9 \mathrm{FTE}$
$1.0-1.9 \mathrm{FTE}$
$\square 0.5-0.9$ FTE
$\square$ Less than 0.5 FTE

4. When was your most recent assessment conducted?

$\square 1985$ to $1989 \quad \square 1990$ to $1994 \quad \square 1995$ to 1999

$\square 2000 \quad \square 2001 \quad \square 2002$

2003

5. Did you receive grant funding to pay for the assessment?

$\square$ Yes $\square$ No $\square$ Do not know

6. How much time do you estimate was spent in advance of the site visit preparing for the review? Include committee time, application/contract preparation, etc.

$\square$ Less than 20 hours $\quad \square 20$ to 40 hours $\quad \square 41$ to 100 hours $\quad \square$ More than 100 hours $\square$ Do not know

7. Your major goals for undertaking an assessment were to: Check all that apply

$\square$ Increase staff awareness of preservation $\square$ Increase administrative support

$\square$ Increase staffing for preservation $\quad \square$ Increase the budget for preservation

$\square$ Improve storage practices

$\square$ Improve pest management

$\square$ Improve exhibition practices

$\square$ Improve the environment

$\square$ Advance repair activity

$\square$ Do not know

Develop a preservation plan

$\square$ Improve the facility

$\square$ Improve security

$\square$ Advance reformatting activity

$\square$ Other (please describe):

8. Did your institution complete a "pre-survey questionnaire" to help familiarize your assessor with the institution in advance of the site visit?

$\square$ Yes $\square$ No $\square$ Do not know

9. The expert who conducted your general preservation assessment was: Check one

$\square$ Outside assessor $\square$ Staff member $\quad \square$ Volunteer $\quad \square$ Student $\quad \square$ Do not know $\square$ Other (please describe):

10. Did your assessor use a guide or tool to direct the assessment?

$\square$ Yes $\square$ No $\square$ Do not know

11. The site visit lasted:

$\square$ Less than 1 day $\quad \square 1$ day $\quad \square 2$ days $\quad \square 3$ to 5 days $\quad \square$ Other (please describe):

12. Do you feel there was adequate time to conduct the site review?

$\square$ Yes $\square$ Too much $\square$ Too little $\square$ Do not know

B. The assessment considered: Check all that apply
$\square$ Organizational context
$\square$ Collections management
Access and use
$\square$ Bibliographic control
$\square$ Emergency management
$\square$ Environmental factors
$\square$ Training needs
$\square$ Security
$\square$ General condition of the collection $\square$ Condition of special collection 
14. Which of the following was included in your assessment report? Check all that apply

$\square$ Executive summary $\quad \square$ Background information on preservation topics

$\square$ Observations from the site visit organized by preservation topic

$\square$ List of recommended preservation actions organized by priority

$\square$ Information to achieve the required preservation actions

$\square$ Appendices with further resources $\square$ No report was issued $\quad \square$ Do not know $\square$ Other (please describe):

15. After the site visit your assessor: Check all that apply

$\square$ Discussed recommendations before submitting a report $\quad \square$ Delivered an oral report of findings

$\square$ Inquired if there were corrections, concerns, etc. $\square$ Requested your evaluation of the assessment

$\square$ Responded to requests for further information $\quad \square$ Discussed implementation strategies

$\square$ Provided no follow-up services $\quad \square$ Do not know $\quad \square$ Other (please describe):

16. How much time did the staff spend after the site visit reviewing the findings generated from the assessment?

$\square$ Less than 20 hours $\square 21$ to 40 hours $\square 41$ to 100 hours $\square$ More than 100 hours $\square$ Do not know

17. How long after the conclusion of assessment (i.e., report delivery) did you begin to implement findings? Check one

$\square$ Less than 2 weeks $\quad \square 2$ to 4 weeks $\square 1$ to 3 months $\quad \square 3$ to 6 months $\quad \square 6$ months to 1 year

$\square 1$ to 2 years $\square$ More than 2 years $\square$ Do not know $\square$ No findings were implemented

18. Did you draft a written preservation plan based on the information provided by the assessment?

$\square$ Yes $\square$ No $\square$ Do not know

19. Have you updated your preservation goals and objectives since your assessment was conducted?

$\square$ Yes $\square$ No $\square$ Do not know

20. Since your assessment administrative and staff support of preservation has: Check one

$\square$ Increased $\square$ Decreased $\square$ Stayed the same $\square$ Do not know 


\section{Part II: Outcomes}

21. The following are recommendations that might be reported based on findings of a general preservation assessment. Please indicate if they were recommended to you and, if yes, whether or not they were accomplished.

\begin{tabular}{|c|c|c|c|c|c|c|}
\hline \multirow[t]{2}{*}{ RECOMMENDATION } & \multicolumn{3}{|c|}{$\begin{array}{l}\text { RECOMMENDED } \\
\text { AS PART OF } \\
\text { ASSESSMENT } \\
\text { Check One }\end{array}$} & \multicolumn{3}{|c|}{$\begin{array}{l}\text { RECOMMENDED \& ACCOMPLISHED } \\
\text { SUBSEQUENT TO ASSESSMENT } \\
\text { Check One }\end{array}$} \\
\hline & YES & NO & $\begin{array}{l}\text { Do not } \\
\text { know }\end{array}$ & Accomplished & $\begin{array}{c}\text { Partially } \\
\text { Accomplished }\end{array}$ & Not Accomplished \\
\hline \multicolumn{7}{|l|}{ Form a preservation committee } \\
\hline \multicolumn{7}{|l|}{$\begin{array}{l}\text { Change the organizational mission } \\
\text { to include preservation }\end{array}$} \\
\hline \multicolumn{7}{|l|}{$\begin{array}{l}\text { Conduct further assessments of the } \\
\text { building or collections }\end{array}$} \\
\hline \multicolumn{7}{|l|}{$\begin{array}{l}\text { Have collection materials } \\
\text { appraised }\end{array}$} \\
\hline \multicolumn{7}{|l|}{$\begin{array}{l}\text { Obtain outside funding for preser- } \\
\text { vation activities }\end{array}$} \\
\hline \multicolumn{7}{|l|}{$\begin{array}{l}\text { Reallocate existing resources for } \\
\text { conservation/preservation activities }\end{array}$} \\
\hline \multicolumn{7}{|l|}{$\begin{array}{l}\text { Hire additional staff to assist with } \\
\text { preservation activities }\end{array}$} \\
\hline \multicolumn{7}{|l|}{$\begin{array}{l}\text { Provide staff with preservation } \\
\text { training }\end{array}$} \\
\hline \multicolumn{7}{|l|}{$\begin{array}{l}\text { Assign preservation responsibilities } \\
\text { as part of staff job descriptions }\end{array}$} \\
\hline \multicolumn{7}{|l|}{$\begin{array}{l}\text { Improve structural design of facil- } \\
\text { ity where collection is stored/used }\end{array}$} \\
\hline \multicolumn{7}{|l|}{$\begin{array}{l}\text { Improve structural integrity of } \\
\text { facility where collection is stored/ } \\
\text { used }\end{array}$} \\
\hline \multicolumn{7}{|l|}{$\begin{array}{l}\text { Construct a better facility for stor- } \\
\text { age and/or use of the collection }\end{array}$} \\
\hline \multicolumn{7}{|l|}{$\begin{array}{l}\text { Relocate to a better facility for } \\
\text { storage and/or use of the collection }\end{array}$} \\
\hline \multicolumn{7}{|l|}{$\begin{array}{l}\text { Write an emergency prevention } \\
\text { and response plan }\end{array}$} \\
\hline \multicolumn{7}{|l|}{ Improve or install: } \\
\hline \multicolumn{7}{|l|}{ Plumbing } \\
\hline \multicolumn{7}{|l|}{ Physical access } \\
\hline \multicolumn{7}{|l|}{ Physical security } \\
\hline \multicolumn{7}{|l|}{ Lighting } \\
\hline \multicolumn{7}{|l|}{ Environmental controls } \\
\hline \multicolumn{7}{|l|}{ Environmental monitors } \\
\hline \multicolumn{7}{|l|}{ Air filtration } \\
\hline Physical security & & & & & & \\
\hline
\end{tabular}




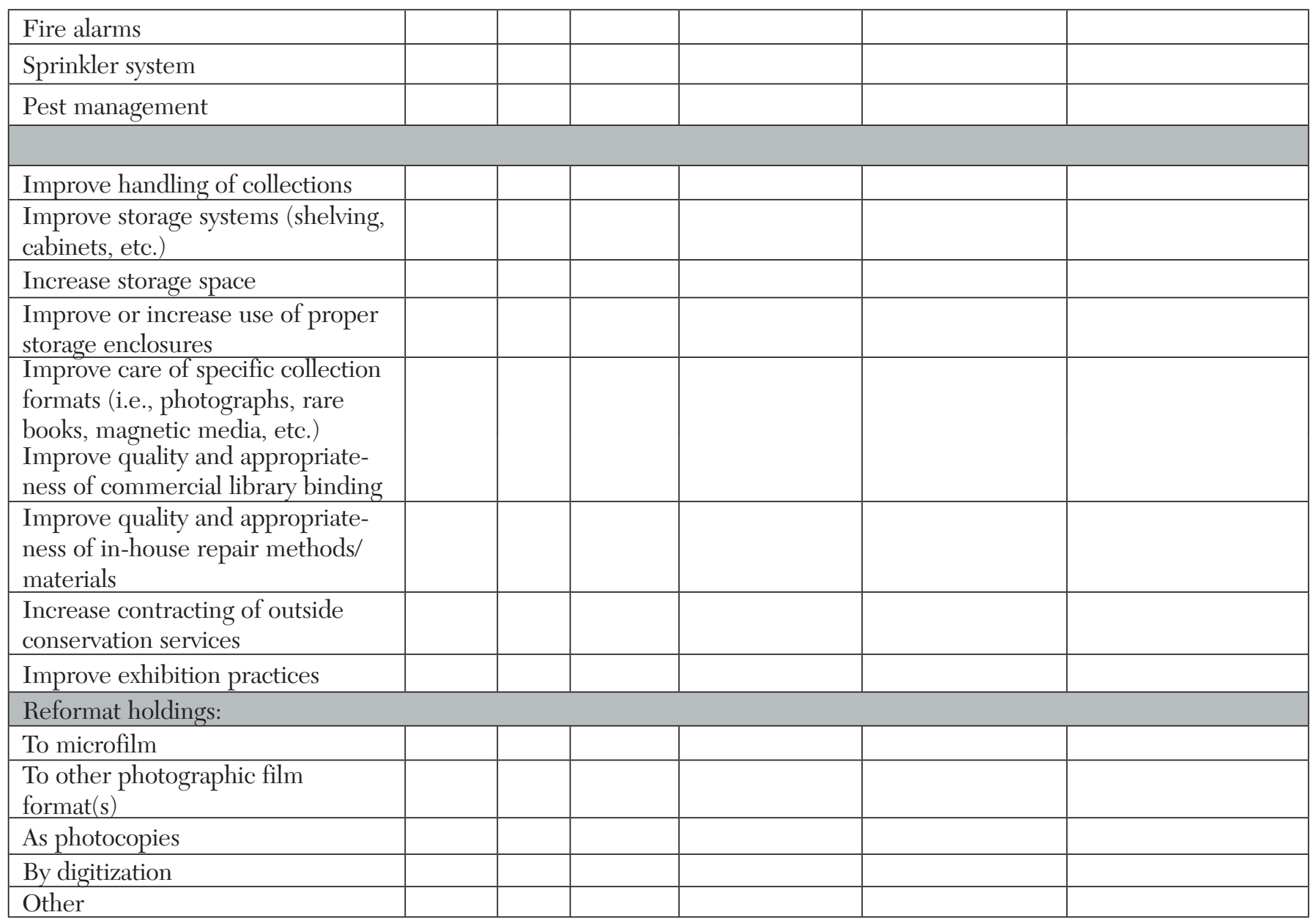

22. Which of the following may have hindered your institution's ability to implement preservation recommendations. Check all that apply

$\square$ Change in administration $\square$ Change in institutional mission $\square$ Change in organizational structure

$\square$ Shift in organizational priorities $\square$ Reduced staffing levels organization-wide

$\square$ Need for further information about best practices on preservation topics

$\square$ Need for further preservation training

$\square$ Reduced staffing levels in preservation units $\square$ Decreased institutional funding

$\square$ Disaster resulting in significant loss of the collection $\square$ Transfer of collection to other institution

$\square$ None $\square$ Other (please describe):

23. Please provide any comments you might have about ways that might improve the general preservation assessment in the space below.

Thank you for your input and assistance with this project. Please respond by November 30, 2003, using the selfaddressed, stamped envelope provided or mail to:

Karen Brown, Preservation Librarian

University at Albany Libraries LE310

1400 Washington Ave.

Albany, NY 12222 